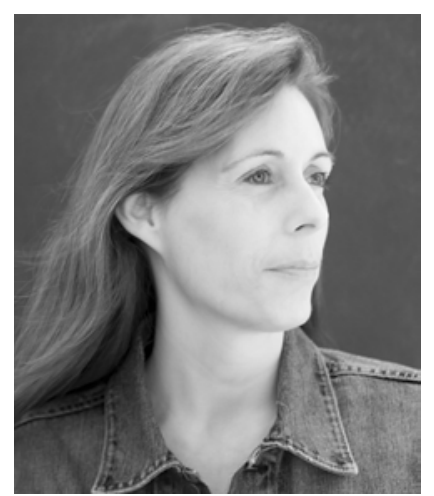

\title{
The Mystery and Magic of Story:
}

\author{
A Spell that Connects One Heart to Another
}

\section{Adapted from a presentation at the 2005 ALAN Workshop, in Pittsburgh, Pennsylvania.}

A couple of months ago, I went home again. I moved back to northern New York State. To understand the significance of this, you need to know that I fled the region at age 18 at a full gallop. I vowed never, ever, ever, ever to return again.

And then God chuckled.

After a lifetime away, I moved home to marry my childhood sweetheart, a carpenter, and join him in the house he built on a hill covered with maple trees. Our home has too many books to count, a collection of oil lamps, and two fireplaces. This is a good thing because we average twenty feet of snow each winter. We often lose our electricity.

I love it when the power goes out. Scot lights the fires and I light the lamps. We sit close and watch the flames flicker. We talk, read-I write. If a bottle of wine is opened, we often end up singing. Thank goodness the neighbors live far away.

I don't like it quite as much if the power goes out when I'm alone. Coyotes run along the bottom of our hill yipping and calling. My German shepherd paces in front of the dark windows. The wind blows and house creaks. I see ghosts in every corner and anxiously wait for the sound of the familiar truck engine that means my beloved is coming home.

The best thing to do when you are alone, in a storm, in the dark, is to watch the fire. Let the light dance for you, soothe you, warm you. The dark is a deep and scary place. It can seem without end or shape. That's why you have to concentrate on the light —-the firelight, the lamp's flicker, the eyes of a loved one ...

$$
\text { ... or a book. }
$$

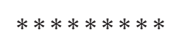

When an author moves to a new home, there is a shift in the Earth's tectonic plates. The accumulated weight of all of the books is staggering. Before I moved, I weeded my collection down to the bare minimum and made truckloads of donations to libraries and friends. Still, my step son developed an impressive set of muscles hauling all those boxes up to my third floor office.

What didn't get weeded out were the letters. Like the other authors here, I get hundreds and hundreds of letters; assigned, unassigned, blog responses, and emails.

People are surprised to hear about the unassigned mail that pours in. Why would a kid take the time to write to me if they don't have to do it for a grade?

If the letter comes from a sexual assault survivor, an outcast, or a depressed kid, usually, she read Speak. If it's a driven academic star who is burning out and frantically trying to hide it, she read Catalyst. If the writer is a teen who is not sure what the point of school is and what to do after graduation, he stumbled across Prom.

(One of my daughters has promised to create an online quiz: "Which Laurie Halse Anderson book are you?")

When the letters started coming in I was confused, too. Why were they writing to me? Why would any teenager write to an author? 
It's quite simple. In story there is magic, words wound in a spell that mysteriously connects one heart to the next. Katherine Paterson says that literature "has a healing quality, a quality that enlarges our human spirits." She also says that "a great novel is a kind of conversion experience. We come away from it changed."

There is magic on the page-words strung in sequence to create worlds that have loves and losses and bad jokes and truth and characters who feel alive. That magic works in the soul of a reader and helps focus him, helps him see the world a little clearer. The reader feels as close to the author as he does to his best friend, to the person who knows the secrets of his heart and still likes him.

I've gotten letters from every state, from England, from Germany, from Italy, and Slovenia. From jail cells. From houses that feel like jails. Many of these letter writers insist that they hate reading, that they hate books, and that my book was the first one they've finished since (fill in the blank) fourth, fifth, sixth grade.

These letter writers usually mention their teachers. Did you know that? They tell me about you, the teacher who assigns books that have meaning to students, who hands books to kids that are not part of the curriculum, who use their own money to replace the books that are stolen over and over again from their classroom collection. I get letters from the kids who pretend they're not listening.

Your best students, your most troubled students, and all the kids in-between are connecting to the literature that you are working so hard to share with them. You are passing along the light of our collective experience, our wisdom and magic. It's working.

If you are here today, you are a great teacher or you will be a great teacher. Not because you're smart, though you are. Not because you keep up-to-date with the latest research, though you do.

It's because you give a damn. You are not content to phone it in. You don't hide in the faculty lounge or your car during break. You give your all, you give every ounce of patience, honesty, hard work and discipline to your students. You leave each night as exhausted as a professional athletes because you leave without a reader.

it all on the field. Pro athletes only play 20, 30, 60 games a year. You play 185 .

Authors are granted the ability to transfigure words into storyinto poetry, novels-epics, even. (Fantasy authors always write the epics. Why is that?) But the ability to twist characters together with plot is worth absolutely nothing

The author tends the tree that grows into story and provides the fuel. Anyone who has tried to camp on a rainy day knows that it is not much fun sitting around watching a pile of wet logs turn moldy. You need the spark, the persistent flame that will catch the wood and bring it to life in all of its heat and glory and light-illuminating the faces of the cold, wet campers, illuminating the lives of the millions of teenagers who are desperate for that glow.

It is very easy to get caught up in the changes of our society, in the stupid "evils" that silly people like to attribute to teenagers. They are allegedly oversexed, undereducated, immoral, drug and technologyaddicted, disrespectful, tattooed, pierced, branded, illiterate, overweight, anorexic, celebrity-addled, halfnaked, spoiled, undisciplined little brats.

You and I both know that is ridiculous. Today's teens exhibit fine, righteous qualities. They are smart and funny. They form friendships across lines of gender, race, class and ethnic background. They enjoy community service. They are artistic, adventurous, and optimistic. They are stepping up to the plate and preparing to make this world a better place.

Gifted, dedicated teachers like you have an awful lot to do with that. You fight for education in the face of ignorance, you battle for literacy and justice and morality and peace.

Robert Cormier said, "My heroes are the ordinary people who do their duty quietly, without fanfare, whether it's fighting a war or going to work every day. I feel that we are surrounded by heroes and saints in our daily lives."

He's right. We are surrounded by heroes and saints in our daily lives. We are surrounded by teachers who burn in the darkness, who offer comfort 
to the cold and weary, who brighten hearts and minds with enlightenment and illumination.

I'm headed north in a little while. Headed back home, where we've already seen snow a couple times. We're renting a splitter this weekend because we have a mountain of logs in front of the garage that need to be split and stacked. Our son who built his muscles hauling books this summer will be hauling firewood on Saturday. (Please do not tell him this.)

The next time you see a fire in a fireplace, or you light a candle, think of me holed up on a stormy night, scratching by the light of an oil lamp. Think of all of us authors scribbling, typing, crossing out, revising, muttering, revising again.

Think of the editors who counsel us, prod us, do their own muttering, some cursing, and shepherding. But mostly, think of your own role in the storytelling process.

You are the light. You are their light. A world of grateful readers thanks you for teaching them.

So do I.
We are surrounded by teachers who burn in the darkness, who offer comfort to the cold and weary, who brighten hearts and minds with enlightenment and illumination.

\section{ALAN Foundation Research Grants}

Members of ALAN may apply to the ALAN Foundation for funding (up to $\$ 1,500$ ) for research in young adult literature. Proposals are reviewed by the five most recent presidents of ALAN. Awards are made annually in the Fall and are announced at the ALAN breakfast during the NCTE convention in November. The application deadline each year is September 15th.

\section{Gallo Grants}

The Gallo Grants were established in 2003 by former ALAN Award and Hipple Award recipient Don Gallo to encourage educators in their early years of teaching to attend the ALAN Workshop for the first time. The grants provide funding - up to $\$ 500$ each - for two classroom teachers in middle school or high school each year to attend the ALAN Workshop. (The amount of a grant may be less than $\$ 500$ if the applicant lives within commuting distance of the convention location where airfare and housing would not be necessary.) The Workshop is held at the annual convention of the National Council of Teachers of English on the Monday and Tuesday prior to Thanksgiving Day. Applicants must be teaching full-time; must have been classroom teachers for less than five years prior to the year in which they are applying; and must not have attended an ALAN Workshop previously. Membership in ALAN is not required for consideration, though applicants are expected to become ALAN members if they receive this grant.

Each applicant must fill out the attached grant application form and submit an essay of no more than 750 words explaining their interest in Young Adult Literature, what they hope to gain by attending this year's ALAN Workshop, and how they hope to use the experience in their classrooms in the future. A letter of support must also come from the applicant's school system. The deadline for submission is September 1 . Applicants will be judged on their ability to articulate their understanding of the value of Young Adult Literature as well as their explanation of how they intend to use YA books and the information they gather at the Workshop in their own classrooms.

For further information about this grant, contact ALAN Executive Secretary Gary Salvner at gsalvner@ysu.edu or 330-941-3414. Information about the ALAN Workshop may be obtained from the ALAN Website-www.alan-ya.org. Information about the NCTE Convention may be obtained on the NCTE Website—www.ncte.org—or by writing to NCTE Headquarters at 1111 West Kenyon Road, Urbana, IL 61801. 